\title{
Prevention of Inflammatory Complications upon Surgeries in Maxillofacial Region
}

\author{
Oleksii 0. Tymofieiev', Natalia 0. Ushko², Oleksandr 0. Tymofieiev², \\ Mariia 0. Yarifa ${ }^{4}$, levgen I. Fesenko ${ }^{5, *}$ \\ ${ }^{1}$ Chair of the Department of Maxillofacial Surgery, Stomatology Institute, Shupyk NMAPE, Kyiv, Ukraine (Prof, ScD) \\ 2 Department of Maxillofacial Surgery, Stomatology Institute, Shupyk NMAPE, Kyiv, Ukraine (Assoc Prof, PhD) \\ ${ }^{3}$ Department of Stomatology, Stomatology Institute, Shupyk NMAPE, Kyiv, Ukraine (Assoc Prof, ScD) \\ ${ }^{4}$ Department of Oral and Maxillofacial Surgery, PHEE "Kyiv Medical University", Kyiv, Ukraine (Assoc Prof, PhD)

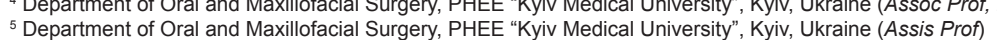

\section{ABOUT ARTICLE}

Article history:

Paper received 25 April 2017

Accepted 03 May 2017

Available online 30 June 2017

\section{Keywords:}

"Stepped" antibiotic therapy

Inflammatory complications

Clean surgeries

Conditionally clean surgeries

Contaminated surgeries

Purulent surgeries

\begin{abstract}
A B S T R A C T
Summary.

Conducting of prophylactic antibiotic therapy in patient after surgical interventions in oral and maxillofacial surgery reduces the incidence of postoperative infectious complications. The analysis of the clean, conditionally clean, dirty (potentially infected), and purulent surgeries is performed. The general questions of prophylaxis of infection complications in plastic, orthognathic, purulent surgeries, and oral microflora are considered. Consecutive cases of postoperative complications and purulent conditions at the head and neck areas are presented. Recommendations on the antibiotic prophylaxis in oral and maxillofacial surgery are given.

(C) Diagnostics and Treatment of Oral and Maxillofacial Pathology. Published by OMF Publishing, LLC. All rights reserved.
\end{abstract}

Recently, a number of patients with purulentinflammatory complications in maxillofacial region is critically increased and the clinical course of the disease is aggravated $[1,2]$. Despite of all comprehensive achievements of medicine the problem of inflammatory complications which manifests after performed operative interventions, is still actual. The frequency of postoperative wounds suppuration is directly dependent on the degree of purity of the surgical wound. It should be noted that after performance of the clean operations (removal of tumors, dental implantation, etc.) the incidence of infectious complications also remains at a high level. Clinical observation revealed that in the case of clean surgeries it is impossible completely eliminate the cases of suppuration of postoperative wounds. Despite the fact that performing of measurements associated with asepsis is obligatory in medical institutions, we cannot exclude microbial contamination of the surgical wound, because both the patient himself and the operating team may be a source of microbial contamination. Postoperative inflammatory

* Corresponding author. Department of Oral anf Maxillofacial Surgery, PHEE "Kyiv Medical University", 4-a Pidvysotskogo Street, Kyiv 01103. Ukraine. Tel.: +38 (097) 3015592.

E-mail address: i.i.fesenko@dtjournal.org (le.l. Fesenko)

Instagram: @dr_eugenfesenko complications should be considered as a factor leading to the significant aggravating of the postoperative period, and it increases the patient's risk of disability.

It is widely believed that the risk of postoperative inflammatory complications depends largely on the level of immunity and age, as well as associated pathology and chronic intoxication of the patient (alcohol and drug addiction). According to our observations the level of immunity in the maxillofacial patients is not at a high level. Many diseases of the maxillofacial region are likely to disrupt the power function and, consequently, reduce the patient's immunity. Due to the environmental problems and changes in the living conditions the doctors often have to deal with immunologically weakened patients. It should be noted that in recent years the increased contingent of elderly patients, as well as those after effects of stress, trauma and with concomitant diseases, is increased. Factors that may contribute to the development of postoperative infectious complications are: violation of aseptic conditions, elderly age, obesity, inadequate hemostasis, significant blood loss, the degree of tissue damage in the area of the surgical wound, use of electrosurgical cautery, violation of technique and the duration of the operation, use of drainage of postoperative wounds, and others.

All operations depending on the risk of postoperative infectious complications after surgical interventions in 

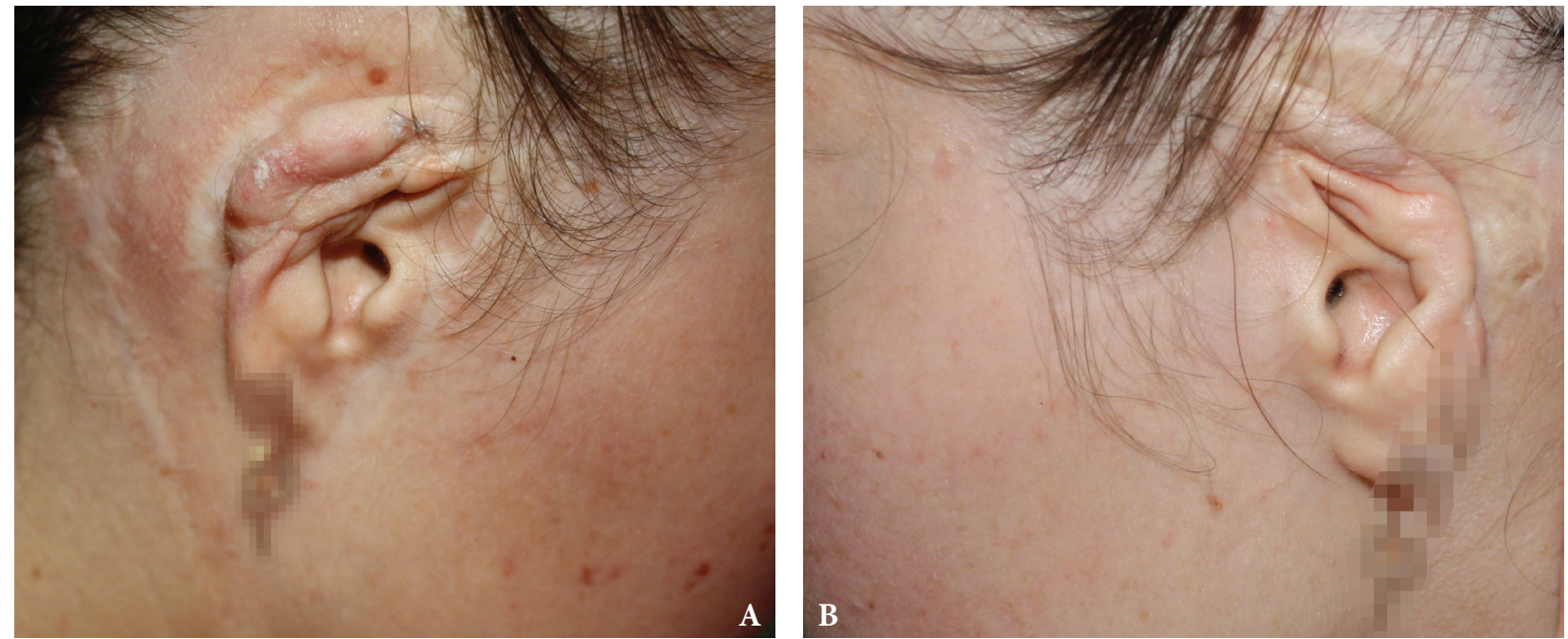

FIGURE 1. Clinical view of the patient after plastic surgery (clean surgery) resulted in postoperative infection complication and scar deformities. Noted the ears deformity and scars in the pre- and postauricular regions $(\mathbf{A}, \mathbf{B})$.

maxillofacial surgery can be divided into the following groups:

- Clean surgeries are an extraoral surgeries which do not penetrate into the oral cavity (blepharoplasty, plastic surgery of the face and neck (Fig 1), as well as removal of tumors and tumor-like formations of the parotid and submandibular glands, etc.) [4-7];

- Conditionally clean are the surgeries, which are performed by an extraoral approach, but there is a risk of penetration into the oral or nasal cavity, as well as operations after elimination of previously existing inflammation (osteosynthesis of the mandible, removing of branchial cleft cysts and fistulas, etc.) [8-11];

- Dirty or potentially infected (contaminated) are the surgeries which are performed by an intraoral approach (resection of teeth roots, dental implants, highmorotomy (Fig 2), removing of lesions in area of alveolar process and body of maxilla and mandible, surgical debridement of the wounds (Fig 3), etc.) [8, 12-16];

- Purulent surgeries are the surgical intervention on the lancing of purulent periostitis, abscesses (Fig 4), phlegmons, sequestrectomies, etc $[17,18]$.
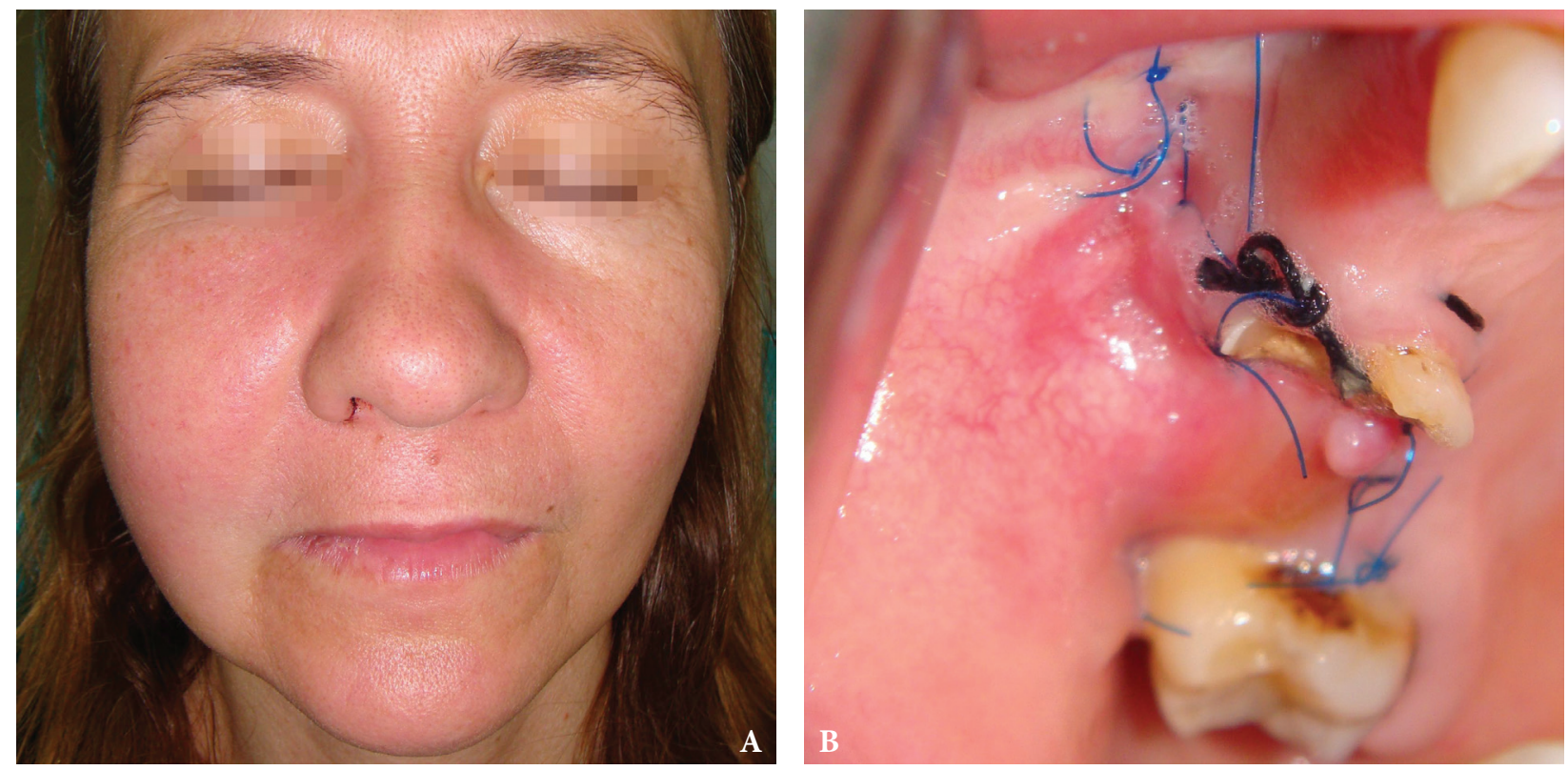

FIGURE 2. Suppuration of the blood clots in the maxillary sinus at 4 day after right-side highmorotomy. The patient complained of increasing of swelling at the right infraorbital and cheek regions, pain. At the clinical photograph of the patient noted hyperemia of the skin $(\mathbf{A})$ and mucosa $(\mathbf{B})$ at the area of surgery. The complication happened as a result of antibiotics rejection and inadequate treatment by non-steroid anti-inflammatory drugs by the patient. 


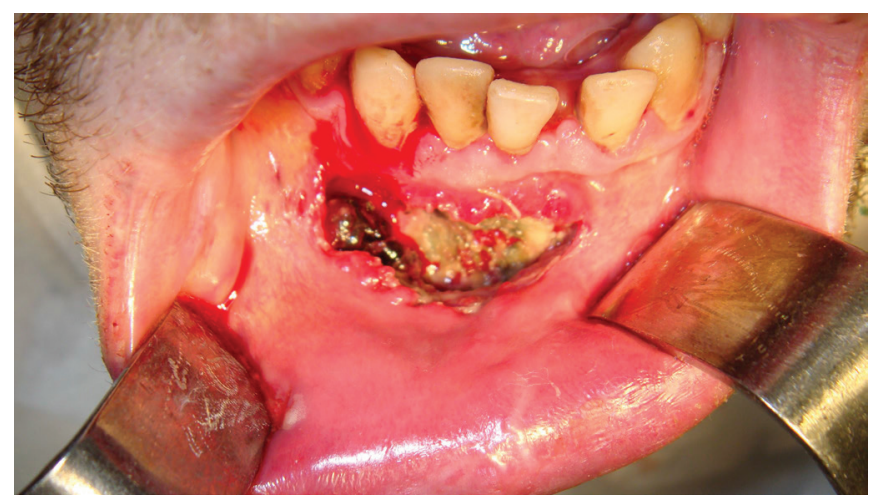

FIGURE 3. Clinical view of infected wound of oral vestibule 3 days after its primary surgical debridement. Sutures fail, suppuration with tissues necrotizing are observed because of violation of the surgeon's recommendations by the patient (rejection of antibiotics, bad oral hygiene, and alcohol abuse).
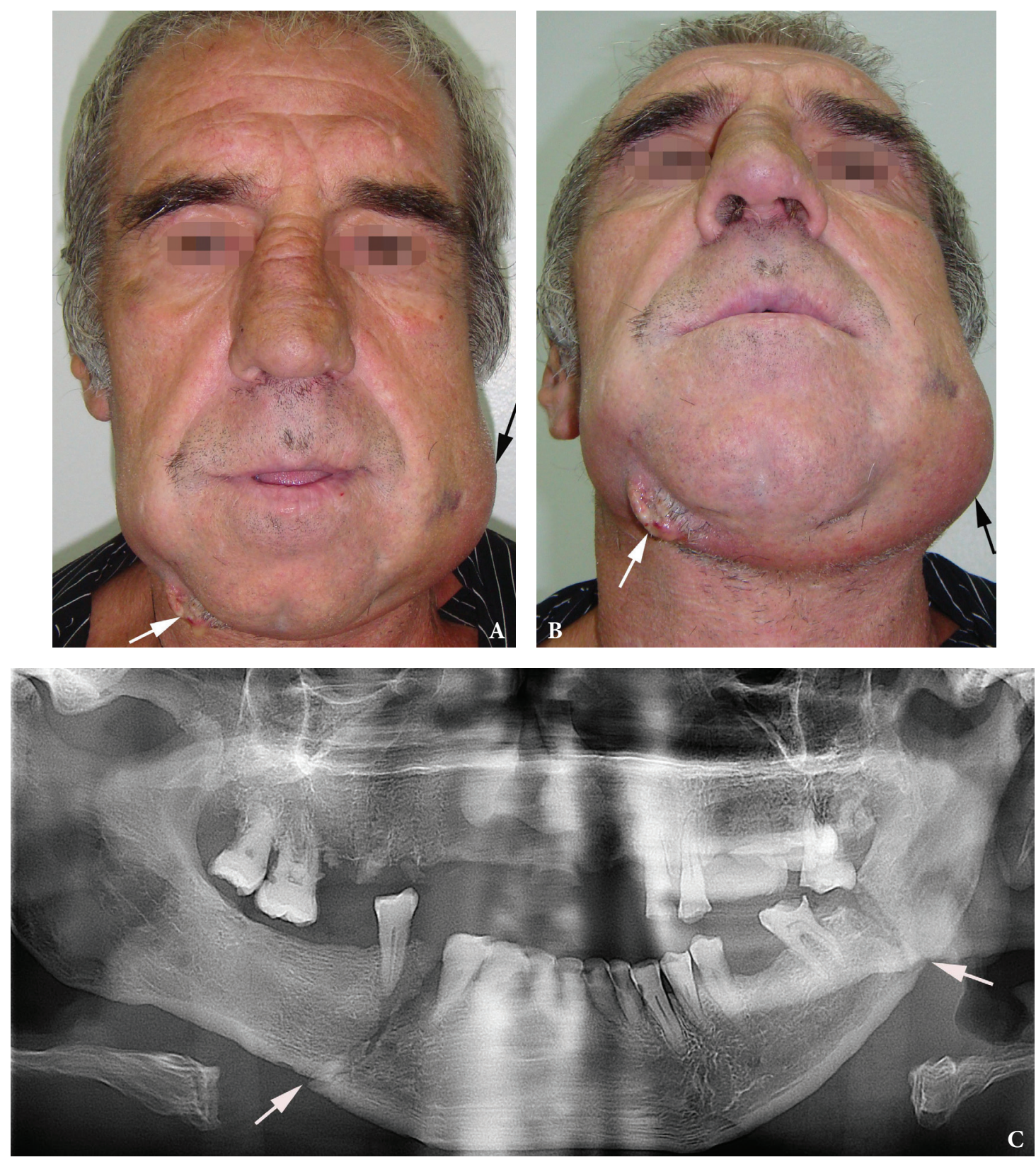

FIGURE 4. 42-year-old patient with two-week bilateral mandibular fracture complicated with osteomyelitis, skin necrosis and of abscess of soft tissues. On the clinical images (A, B) the skin necrosis with purulent discharge is indicated by white arrows, abscess - black arrows. Panoramic x-ray (C) shows mandibular fractures (arrows) with dislocations. 
Antibiotic prophylaxis is intended to reduce the likelihood of surgical wound contamination by the pathogens and prevent further microbial growth.

Preoperative antibiotic prophylaxis is only a supplement, not an alternative to good surgical technique of operation. If the infectious process was already running at the time of surgery, the administration of prophylactic antibiotics 3-4 hours after its performance is already ineffective.

Considering the specifics of work of the maxillofacial and oral surgeons, we would like to dwell on the microflora of the mouth. Species composition of oral microflora in healthy people is fairly constant. The number of microorganisms varies depending on the salivation, consistency and nature of the food, oral hygiene, the state of the tissues and organs of the oral cavity and the presence of systemic diseases. In the oral cavity a large number of different species of bacteria is contained, much greater than in other parts of the gastrointestinal tract. A significant number of contained types of microorganisms can also be explained by the fact that the bacteria enter into the oral cavity with air, water, food, i.e. they are so-called transit microorganisms, stay of which is limited.

The oral microflora is permanent, contains nearly 30 microbial species, it forms a stable and fairly complex ecosystem of the oral cavity. Thus, the mouth is a type of ecological system, which is closely related to the internal medium of the organism and its environment. An integral part of micro-ecosystem of the oral cavity is normal microflora that provides colonization resistance, which is seen as the primary target for any factor which directly or indirectly affects the non-specific resistance of this ecosystem. Permanent microflora of the human oral cavity is formed as a result of mutual adaptation of the organism and microbes. Adaptive and related biological changes lead to «balance» between a human body and the microbial flora, and between the components of its species of microorganisms. This "equilibrium" is of dynamic type.

Disorders of salivation, chewing and swallowing always lead to an increase in the number of microorganisms in the oral cavity. The same effect is observed in a variety of anomalies, defects and diseases that hinder leaching micro-organisms by saliva flow (carious lesions, periodontal pockets, poorly manufactured non-removable dentures, inflammatory processes around the jaws, etc.).

The composition of the microbial flora of the oral cavity is not uniform. In different areas the various quantitative and qualitative composition of microorganisms are defined. The microflora of the oral cavity varies extremely and includes bacteria, actinomycetes, fungi, protozoa, spirochetes, rickettsia, viruses. It should be noted that some part microflora of oral cavity of adults are anaerobic species. There are obligate and facultative anaerobes. Obligate anaerobes are killed in the presence of free oxygen in the environment. Facultative anaerobes can persist and proliferate in oxygen or in oxygen-free environment. The facultative anaerobes are E coli, staphylococcus, streptococcus and other bacteria. Obligate anaerobes can be divided into two groups: bacteria, spores forming (Clostridium) and bacteria (Non-clostridial) anaerobes. Among the bacteria which form spores, anaerobic pathogens clostridial infections are distinguished, i.e., gas gangrene [21-25]. The non-clostridial anaerobes include: Bacteroides, Fusobacteria, Veilonellas, Peptococcus, Peptostreptococcus, Eubacteria, etc.

In the mouth, the saliva affects microorganisms, mechanically washing out bacteria and by containing antimicrobial agents (lysozyme). But in the oral cavity, there are always areas easily colonized by microorganisms (gingival pockets, gaps between teeth, teeth eruption). The highest concentrations of microbial colonies in adults are formed in the interdental spaces, physiological gingival pockets (gingival sulcus), dental plaque, in the retromolar space, in the area of the tonsils and back of the tongue, especially in its posterior parts.

The composition of oral microflora includes microorganisms, some of which are forms of autochthonous flora, while others - allochthonous (inherent in other areas). Autochthonous flora consists of local microorganisms which are characteristic of the oral cavity. Among the autochthonous microorganisms the resident (obligate) and transient species are distinguished. Allochthonous microflora of the mouth is represented by microbes inherent in other areas (it is composed of species that normally live in the intestines, nose and throat and other parts of the human body).

Microflora of the mouth also can be divided into two groups: a constant (physiological or normal) microflora, i.e. set of different species of microorganisms, which is characteristic of a healthy person; random (transient) microflora is a saprophytic and pathogenic microorganisms which enter the oral cavity from the outside (after surgery, etc.).

The qualitative composition of the resident microflora of the mouth of every healthy person varies in a limited extent. It is known that among the bacterial flora of the oropharynx the streptococci dominate. The majority of Gram-positive cocci oral represented a heterogeneous group of low virulence viridans streptococci, which are actively involved in the processes that lead to lesions of dental hard and periodontal tissues. This group includes Streptococcus mutans, S sanguis, S mitis, S salivarium. Often they are found jointly with Fusobacteria and Spirochetes during caries, pulpitis, periodontitis, abscesses of the maxillofacial region. The second group of Gram-positive cocci are Peptococci.

Less aerated areas are colonized by anaerobes Actinomycetes, Bacteroides, Fusobacteria Veilonellas. The genus Fusobacterium is bacteroids with autochthonous flora of the mouth. Fusobacteria live in gingival pockets with Spirochetes association. Gram-negative 
anaerobic cocci are represented by genus Veillonella and are permanent inhabitants of the oral cavity of man. Veillonella concentration in saliva is approximately the same as that of Streptococci viridans. Most often there are two types of Bacteroides - $V$ melaninogenicus, B gingivalis. $\mathrm{B}$ melaninogenicus is a regular inhabitant of the gingiva in adults and has a great pathogenetic importance in the development of periodontal diseases.

In oral cavity, there are the Spirochaetes genera of Leptospira, Borrelia and Treponemas, Mycoplasmas ( $M$ orale, $M$ salivarium), Candida species and a variety of Protozoa (Entamoeba buccalis and $E$ dentalis, Trichomonas buccalis). In the oral cavity, there are also genera Actinomyces and Bifidobacterium. Actinomycetes are on the oral mucosa, may participate in the formation of dental plaque and caries and periodontal diseases. Very often in these pathological processes A viscosus and A israelii are found. A viscosus is involved in the formation of subgingival calculus.

In the oral cavity, bacteria genus Corynebacterium is found. A characteristic feature of Corynebacterium is its ability to reduce the redox potential, thereby creating conditions for the growth of anaerobes. In case of periodontal diseases they are found in association with Fusobacteria and Spirochetes. Thus, the composition of microbial species, which are in oral cavity is complex one.

Relative ease of ingress of bacteria from the oral mucosa or other local purulent lesions in the blood stream determines the relatively high incidence of oral sepsis. The presence in the oral cavity of poorely cleaned cavities, gingival pockets and other areas contributes to the persistence of pathogenic microorganisms and causes the formation of a sufficiently high rate of chronic infection foci (Staphylococcal, Streptococcal, etc.) with following allergization of the body.

The main measures for reducing the number of postoperative inflammatory complications are as follows:

- Before carrying out operations it is necessary to sanitize the oral and nasal cavities;

- Special attention should be paid to the reduction of both exogenous and endogenous infections of surgical wounds during the operation, i.e. performing aseptic;

- During an operation it is necessary to take care of the tissues, which reduces the probability of formation of zones of ischemia, necrobiosis and necrosis in the surgical wound;

- Should be a rational and targeted preoperative antimicrobial prophylaxis.

Taking account of the leading role of microorganisms in causing inflammatory processes in maxillofacial area, the prescription of antibacterial therapy no one questiones. Antibiotic therapy is carried out both during the treatment of patients with already arisen abscesses and phlegmons [26-29], and for the prevention of inflammatory complications after a clean, conditionally clean and contaminated (potentially infected) surgical interventions. Routes of administration of antimicrobial drugs, their dosage and duration of prophylactic antibiotic therapy depends on the reactivity of the patient, the volume of the surgery, the presence of concomitant diseases, etc.

Rational prescribing of antibiotic prophylaxis, in terms of reducing the risk of postoperative inflammatory complications during the surgery, no one questiones. The choice of antimicrobial drug for the prevention of postoperative infectious complications is difficult because in the occurrence and development of these processes, usually not one microbial pathogen, but a few - microbial associations are involved. According to some authors - from 3 to $6[1,2]$. When planning prophylactic antibiotics in outpatient it is advisable to focus on the purpose of oral antibiotics with high bioavailability, long half-life and minimal side effects of their actions. In carrying out preventive measures for patients in a hospital environment it is advisable to choose an antibiotic for sequential therapy, i.e. antibacterial drug, which has forms for the parenteral and oral routes of administration.

Requirements to the antibiotic that is used for the treatment and prevention of inflammatory complications are:

- The antibiotic should be active against microorganisms groups, which are most often found in chronic odontogenic inflammatory foci;

- Spectrum of antibiotic activity must comply with possible representatives of microflora characteristic of the treated area;

- The drug must have the least ability to induce resistance of microorganisms;

- Antibiotic should well penetrate into the tissues in which surgery is performed (in operations for opening abscesses and abscesses - in soft tissue, jaw operations the bone);

- The level of the antibiotic in abnormal foci must reach minimum inhibitory concentration and maintain at that level for the required time;

- Antibiotic should provide minimal side effects and does not adversely interact with other medications that may be concurrently used (anesthetics, analgesics, etc.).

It was found that the activity of antibiotics against pathogenic microorganism is not constant; it decreases with time due to formation of antibiotic resistance microbial resistance to antibacterial drugs.

An important requirement for adequate prophylactic antibiotic therapy is the ratio of the value and effectiveness of the antimicrobial agent. For the treatment and prevention of inflammatory complications in maxillofacial region the parenteral route of administration of antibiotics is the most commonly used. At cost indicators, the frequency of side effects and convenience of use oral dosage forms possess significant advantage. In the last decade, we have increasingly observed high efficiency of "stepped" antibiotic therapy (synonyms: sequential, step-down, switch therapy), which occupies an 
increasingly strong position in the practice of medicine. Under step antibiotic therapy the gradual transition from parenteral to oral route of administration for the improvement of the patient's condition is implied. The main criterion for the transition to the reception of the drug inside is the normalization of body temperature or its significant reduction. The transition to the oral route of administration has a number of advantages: reducing the load on the medical staff, material savings, the disappearance of the risk of postinjective complications development (inflammatory infiltrates, phlebitis, etc.) and others. However, the antibiotic, which can be used for sequential therapy must meet certain requirements. The main one is the maximum range of the proximity antibacterial preparations for parenteral or oral route, as well as their high bioavailability (in the serum virtually the same concentration of the drug, regardless of its route of administration, to be created).

\section{Conclusions}

With prophylactic aim the antibiotics should be used in the following surgical interventions: removal of impacted teeth, the apices of the teeth roots resection, cystectomy, dental implants placement, removal of tumors and tumor-like formations, uncomplicated fractures without displacement of jaw fragments, plastic and reconstructive surgeries and other diseases. Assuming division of operations in terms of surgical wound purity, it should be noted that for prophylactic antibiotics for clean, relatively clean and contaminated (potentially infected) operations are indicated. The appointment of antibiotics for purulent operations (abscess and phlegmons treatment, mediastinitis etc.) (Fig 5) $[30,31]$ is indicated for the prevention of secondary complications that may arise as a result of the progression of already developed chronic inflammatory diseases.
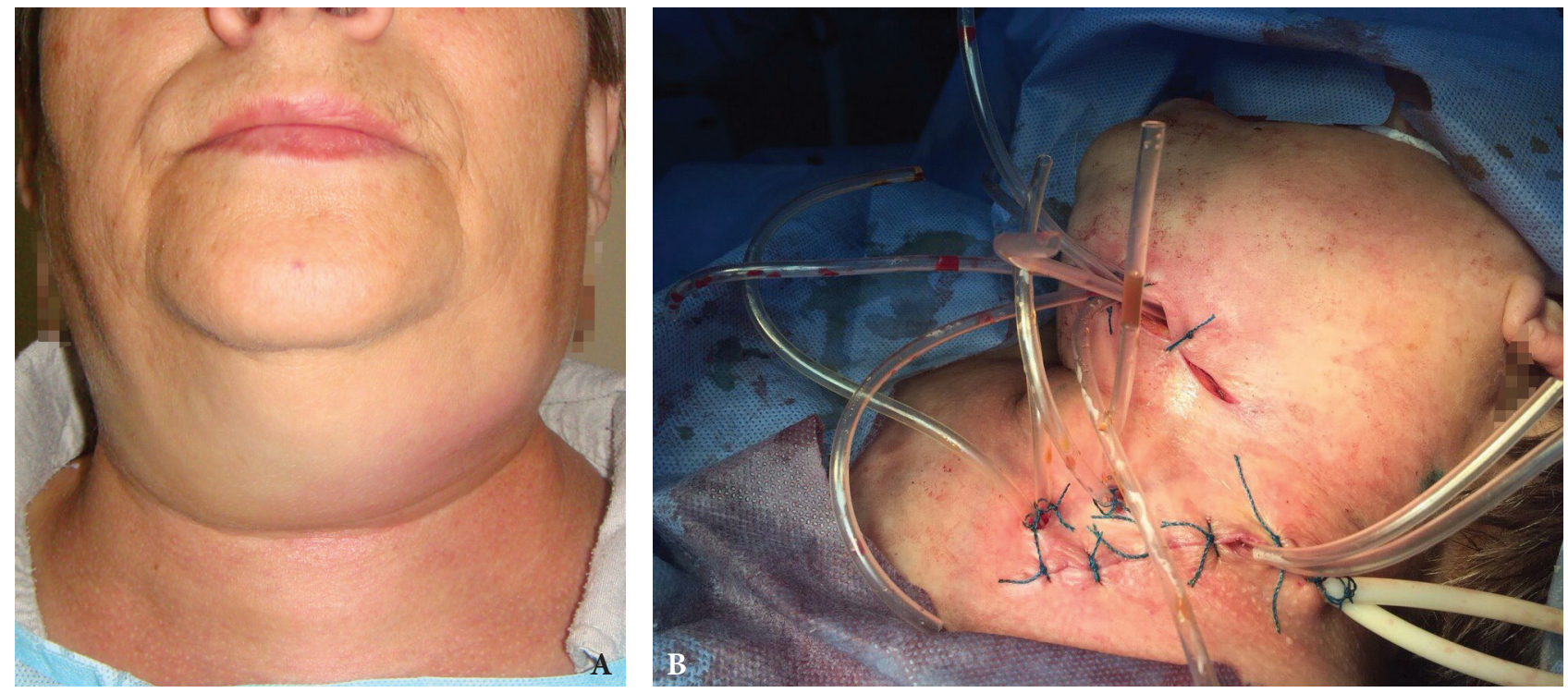

FIGURE 5. 63-year-old woman with the odontogenic phlegmone of tissues of the mouth floor on the left, left neck, and acute purulent anterior superior mediastinitis. Preoperative image (A) shows significant swelling of tissues at the left submandibular region, and left neck. Postoperative image (B) shows fixed surgical drains. (Images of Figure $\mathbf{5}$ are courtesy of Yurii V. Chepurnii, PhD, Assoc Prof, Dr. Andrii M. Karnuta, Dr. levgen I. Fesenko, Assis Prof, Dr. Anna Yu. Romanova; Kyiv, Ukraine)

\section{Funding}

None.

\section{Conflict of Interests}

The authors declare no conflict of interest.

\section{Role of Author and Co-authors}

Oleksii O. Tymofieiev (concept of the paper and writing).

Natalia O. Ushko (material collection).

Oleksandr O. Tymofieiev (material collection).
Mariia O. Yarifa (material collection).

Ievgen I. Fesenko (material collection and editing).

\section{Ethical Approval}

Approval was obtained from the Medical Ethics Committee of the Shupyk National Medical Academy of Postgraduate Education, Kyiv, Ukraine.

\section{Patient Consent}

Written patient consent was obtained to publish the clinical images. 


\section{References}

1. Tymofieiev OO. Rukovodstvo po chelustno-litsevoi hirurgii i hirurgicheskoi stomatologii [Manual of maxillofacial and oral surgery]. 5th ed. Kyiv: Chervona Ruta-Turs; 2012. p. 1048 (in Russian).

2. Tymofieiev OO. Chelyusno-litsevaya hirurhiya [Maxillofacial surgery] 2nd ed. Kyiv: Meditsina; 2015. 800 p. (in Russian).

3. Chen YW, Huang CC, Chang PH, Chen CW, Wu $\mathrm{CC}, \mathrm{Fu} \mathrm{CH}$, et al. The characteristics and new treatment paradigm of dental implant related chronic rhinosinusitis. Am J Rhinol Allergy 2013;27:237-44. http://dx.doi.org/10.5125/jkaoms.2014.40.2.87.

4. Handler EB, Song T, Shih C. Complications of Otoplasty. Facial Plast Surg Clin N Am 2013;21:653-62. http://dx.doi.org/10.1016/j.fsc.2013.08.001.

5. Owsley TG, Biggerstaff TG. Otoplasty complications. Oral Maxillofac Surg Clin North Am 2009; 21(1):10518, vii. http://dx.doi.org/10.1016/j.coms.2008.10.011.

6. Kadouch JA, Tutein Nolthenius CJ, Kadouch DJ, et al. Complications after facial injections with permanent fillers: important limitations and considerations of mri evaluation. Aesthet Surg J 2014;34(6):913-23. http:// dx.doi.org/10.1177/1090820X14539504.

7. Cuzalina LA, Hlavacek MR. Complications of facial implants. Oral Maxillofac Surg Clin North Am 2009;21(1):91-104, vi-vii. http://dx.doi.org/10.1016/j. coms.2008.10.009.

8. Fernandes RP, Quimby A, Salman S. Comprehensive reconstruction of mandibular defects with free fibula flaps and endosseous implants. J Diagn Treat Oral Maxillofac Pathol 2017;1:6-10. http://dx.doi. org/10.23999/j.dtomp.2017.1.1.

9. Chaine A, Pitak-Arnnop P, Hivelin $M$, et al. Postoperative complications of fibular free flaps in mandibular reconstruction: an analysis of 25 consecutive cases. Oral Surg Oral Med Oral Pathol Oral Radiol Endod 2009;108(4):488-95. http://dx.doi. org/10.1016/j.tripleo.2009.05.043.

10. Kim MG, Lee ST, Park JY, Choi SW. Reconstruction with fibular osteocutaneous free flap in patients with mandibular osteoradionecrosis. Maxillofac Plast Reconstr Surg 2015;37:7 http://dx.doi.org/10.1186/ s40902-015-0007-3.

11. Tymofieiev OO, Fesenko IeI, Cherniak OS, Zaritska VI. Features of diagnostics, clinical course and treatment of the branchial cleft cysts. J Diagn Treat Oral Maxillofac Pathol 2017;1:15-31. http://dx.doi.org/10.23999/j. dtomp.2017.1.3.

12. Nam KY, Kim JB. Treatment of dental implant-related maxillary sinusitis with functional endoscopic sinus surgery in combination with an intra-oral approach. $J$ Korean Assoc Oral Maxillofac Surg 2014; 40(2):87-90. http://dx.doi.org/10.5125/jkaoms.2014.40.2.87.

13. Chow LK, Singh B, Chiu WK, Samman N. Prevalence of postoperative complications after orthognathic surgery: a 15-year review. J Oral Maxillofac Surg 2007;65(5):98492. http://dx.doi.org/10.1016/j.joms.2006.07.006.

14. Kim YK. Complications associated with orthognathic surgery. I Korean Assoc Oral Maxillofac Surg 2017;43(1):3-15. http://dx.doi.org/10.5125/ jkaoms.2017.43.1.3.

15. Davis CM, Gregoire CE, Steeves TW, Demsey A. Prevalence of surgical site infections following orthognathic surgery: a retrospective cohort analysis. $J$ Oral Maxillofac Surg 2016;74:1199-206. http://dx.doi. org/10.1016/j.joms.2016.01.040.

16. Posnick JC, Choi E, Chavda A. Surgical site infections following bimaxillary orthognathic, osseous genioplasty, and intranasal surgery: a retrospective cohort study. J Oral Maxillofac Surg 2016. http://dx.doi. org/10.1016/j.joms.2016.09.018.

17. Humber CC, Albilia JB, Rittenberg B. Chronic osteomyelitis following an uncomplicated dental extraction. J Can Dent Assoc 2011;77:b98

18. Gaetti-Jardim EJR, Ciesielski FIN, Possagno R, Castro AL; Marqueti AC, Gaetti-Jardim. Chronic osteomyelitis of the maxilla and mandible: microbiological and clinical aspects. Int J Odontostomat 2010;4(2):197-202.

19. Valour F, Sénéchal A, Dupieux C, et al. Actinomycosis: etiology, clinical features, diagnosis, treatment, and management. Infect Drug Resist 2014;7:183-97. http:// dx.doi.org/10.2147/IDR.S39601.

20. Hansen D, Pollan LD, Fernando H. Fulminant Clostridium difficile colitis: a complication of perioperative antibiotic prophylaxis. J Oral Maxillofac Surg 2013;71(11):1880-5. http://dx.doi.org/10.1016/j. joms.2013.04.035.

21. Fatimi S, Sheikh S, Shafiq M, Shah Z. Non-clostridial gas gangrene of the neck and mediastinum. Asian Cardiovasc Thorac Ann 2007;15(1):e12-3. http://dx.doi. org/10.1177/021849230701500128.

22. Takazawa K, Otsuka H, Nakagawa Y, Inokuchi S. Clinical features of non-clostridial gas gangrene and risk factors for in-hospital mortality. Tokai J Exp Clin Med 2015;40:124-9.

23. Akamatsu H, Sano T, Hayashi T, Shima M, Oishi K. A case of gas gangrene by odontogenic infection. J Jpn Soc Oral Tumors 2008;21:112-6.

24. Tsuchiya Y, Noguchi T, Shinozaki Y, Ito H, Jinbu Y, Kusama M. A case of orbital abscess with gas gangrene caused by odontogenic infection. Jpn J Oral Maxillofac Surg 2012;58:67-71.

25. De A, Varaiya A, Mathur M, Bhesania A. Bacteriological studies of gas gangrene and related infections. Indian J Med Microbiol 2003;21:202-4.

26. Greenberg SL, Huang J, Chang RS, Ananda SN. Surgical management of Ludwig's angina, ANZ J Surg 2007;77(7):540-3. http://dx.doi.org/10.1111/j.14452197.2007.04146.x.

27. Larawin V, Naipao J, Dubey SP, et al. Head and neck space infections. Otolaryngol Head Neck Surg 2006;135(6):889-93. http://dx.doi.org/10.1016/j. otohns.2006.07.007.

28. Viera F, Allen SM, Stocks RM, Thompson J. Deep neck infections. Otolaryngol Clin North Am 2008;41:459-83. http://dx.doi.org/10.1016/j.otc.2008.01.002.

29. Vaid N, Kothadiya A, Patki S, Kanhere H. Necrotising 
fasciitis of the neck. Indian J Otolaryngol Head Neck Surg 2002;54(2):143-5. http://dx.doi.org/10.1007/ BF02968735.

30. Diamantis S, Giannakopoulos H, Chou J, Foote J. Descending necrotizing mediastinitis as a complication of odontogenic infection. Int J Surg
Case Rep 2011;2(5):65-7. http://dx.doi.org/10.1016/j. ijscr.2011.01.004.

31. Roccia F, Pecorari GC, Oliaro A, Passet E, Rossi P, Nadalin J, et al. Ten years of descending necrotizing mediastinitis: management of 23 cases. JOral Maxillofac Surg 2007;65:1716-24.

Tymofieiev 00, Ushko N0, Tymofieiev 00, Yarifa M0, Fesenko lel.

Prevention of inflammatory complications upon surgeries in maxillofacial region.

J Diagn Treat Oral Maxillofac Pathol 2017;1:105-12.

http://dx.doi.org/10.23999/j.dtomp.2017.2.8.

\section{Профілактика запальних ускладнень при операціях в щелепно-лицевій ділянці}

Олексій Олександрович Тимофєєв, Наталія Олексіївна Ушко², Олександр

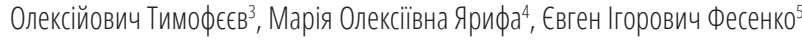

1 завідувач кафедрою щелепно-лицевої хіруреії Інституту стоматології Національної медично

2 Доцент кафредри хірургічної стоматології та щелепно-лицевої хірургії ПвНз “Київський медичний університет", к. мед. н., доцент.

${ }^{3}$ Доцент кафедри стоматології Iнституту стоматології Національної медичної академії післядипломної освіти імені П. Л. Шупика, д. мед. н., доцент.

Доцент кафредри хіруреічноі стоматології та щелепно-лицевої хіруреії ПВНЗ “Київський медичний університет", к. мед. н., доцент.

Асистент кафедри хірургічної стоматології та щелепно-лицевої хіруреії пВНз "Київський медичний університет

\section{ПРО С ТАТТЮ}

P E 3 Ю M E

Історія рукопису:

Отриманий: 25 квітня 2017 року

Прийнятий: 03 травня 2017 року

Онлайн з: 30 червня 2017 року

Ключові слова:

“Ступенева" антибактеріальна

терапія

Запальні ускладнення

"Чисті" операції

"Умовно-чисті" операції

Потенційно чисті операціі

Гнійні операції
Проведення профілактичної антибіотикотерапії у пацієнтів після хірургічних втручань в хірургічній стоматології та щелепно-лицевої хірургії знижує частоту післяопераційних інфекційних ускладнень. Проводиться аналіз “чистих", “умовно-чистих”, “брудних” (потенційно інфікованих) і гнійних операцій. Розглянуто загальні питання профілактики інфекційних ускладнень при проведенні пластичних, ортогнатичних, гнійних операцій і проаналізовано мікрофлору ротової порожнини. Послідовно представлені ряд випадків післяопераційних ускладнень та гнійно-запальних процесів в області голови та шиї. Дані рекомендації по антибіотикопрофілактики в хірургічній стоматології та щелепно-лицевої хірургії.

\section{Профилактика воспалительных осложнений при операциях в челюстно-лицевой области}

Алексей Александрович Тимофеев', Наталия Алексеевна Ушко², Александр Алексеевич Тимофеев ${ }^{3}$, Мария Алексеевна Ярифа ${ }^{4}$, Евгений Игоревич Фесенк $0^{5}$

1 Заведующий каседрой челюстно-лицевой хирургии Института стоматологии Национальной 2едия Доце ${ }^{3}$ Доцент кафедры стоматологии Института стоматологии Национальной медицинской академии последипломного образования имени П. Л. Шупика, д.мед.н., доцент.

Доцент кафедры хирургической стоматологии и челюстно-лицевой хирургии пвуз “Киевский медицинский университет", к. мед. н., доцент.

Ассистент каредры хирургической стоматологии и челюстно-лицевой хирургии ПвУз “Киевский медицинский университет

\section{O C TA T b E}

P E 3 Ю M E

История рукописи:

Получена: 25 апреля 2017 года Принята: 03 мая 2017 года Онлайн с: 30 июня 2017 года

Ключевые слова:

“Ступенчатая” антибактериальная терапия

Воспалительные осложнения

"Чистые" операции

“Условно-чистые” операции Потенциально чистые операции

Гнойные операции
Проведение профилактической антибиотикотерапии у пациентов после хирургических вмешательств в хирургической стоматологии и челюстно-лицевой хирургии снижает частоту послеоперационных инфекционных осложнений. Проводится анализ “чистых", “условно-чистых", “грязных" (потенциально инфицированных) и гнойных операций. Рассмотрены общие вопросы профилактики инфекционных осложнений при проведении пластических, ортогнатических, гнойных операция и микрофлора ротовой полости. Последовательно представлены ряд случаев послеоперационных осложнений и гнойно-воспалительных процессов в области головы и шеи. Даны рекомендации по антибиотикопрофилактике в хирургической стоматологии и челюстно-лицевой хирургии. 